\title{
THE EAST SLOPE NO. 2 URANIUM PROSPECT, PIUTE COUNTY, UTAH
}

This report concerns work done on behalf of the U. S. Atomic Energy Commission and is published with the permission of the Commission.

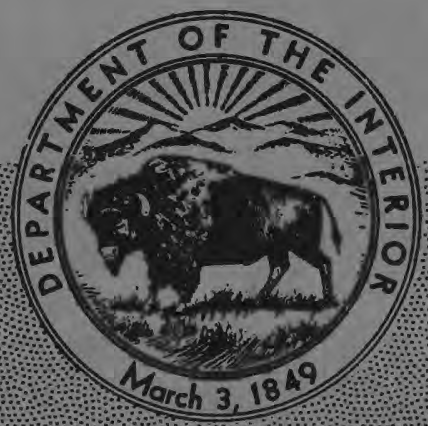


UNITED STATES DEPARTMENT OF THE INTERIOR

Douglas McKay, Secretary

GEOLOGICAL SURVEY

W. E. Wrather, Director

GEOLOGICAL SURVEY CIRCULAR 322

\section{THE EAST SLOPE NO. 2 URANIUM PROSPECT, PIUTE COUNTY, UTAH}

By Donald G. Wyant

This report concerns work done on behalf of the U.S. Atomic Energy Commission and is published with the permission of the Commission. 


\title{
THE EAST SLOPE NO. 2 URANIUM PROSPECT, PIUTE COUNTY, UTAH
}

\author{
By Donald G. Wyant \\ CONTENTS
}

Page

Page

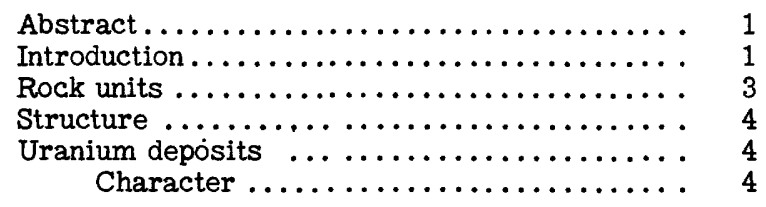

Uranium deposits-Continued

Alteration .................. 4

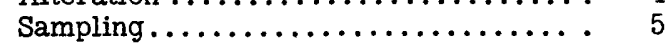

Outlook and guides to prospecting......... 5

Literature cited .................. 6

Unpublished reports ................. 6

\section{ILLUSTRATIONS}

Page

Plate 1. Geologic map and cross sections, East Slope No. 2 uranium prospect,

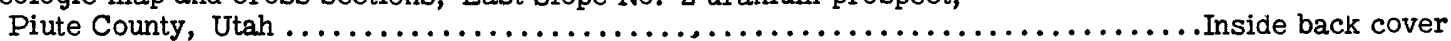

Figure 1. Index and geologic maps of the Marysvale district, Utah, showing the location

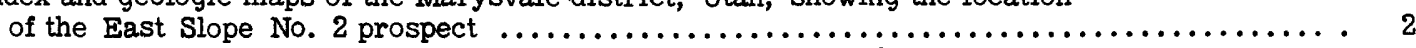

2. Sketch section along west face of the upper cut, East Slope No. 2 uranium prospect,

Piute County, Utah

\section{TABLES}

Page

Table 1. Spectrographic analyses of samples from alteration zones, East Slope No. 2 uranium

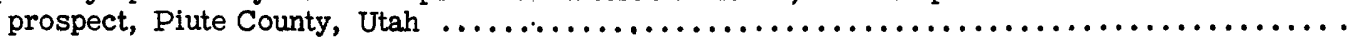

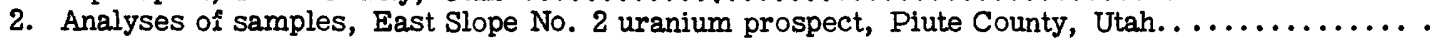

\begin{abstract}
The secondary uranium minerals autunite, metatorbernite, uranophane(?), and schroeckingerite occur in altered hornfels at the East Slope No. 2 uranium prospect. The deposit, in sec. 6, T. $27 \mathrm{~S}$., R. $3 \mathrm{~W}$., Piute County, Utah, is about 1 mile west of the Bullion Monarch mine which is in the central producing area of the Marysvale uranium district.

Hornfels, formed by contact metamorphism of rocks of the Bullion Canyon volcanics bordering the margin of a quartz monzonite stock, is in fault contact with the later Mount Belknap rhyolite. The hornfels was intensely altered by hydrothermal solutions in pre-Mount Belknap time. Hematite-alunite-quartz-kaolinite rock, the most completely altered hornfels, is surrounded by orange to white argillized hornfels containing. beidellite-montmorillonite clay, and secondary uranium minerals. The secondary uranium minerals probably have been derived from pitchblende, the primary ore mineral in other deposits of the Marysvale area.
\end{abstract}

The two uranium-rich zones, 4 feet and 5 feet thick, have been traced on the surface for 60 feet and 110 feet, respectively. Channel samples from these zones contained as much as 0.047 percent uranium.

The deposit is significant because of its position outside the central producing area and because of the association of uranium minerals with alunitic rock in hydrothermally altered hornfels of volcanic rocks of early Tertiary age.

\section{INTRODUCTION}

Uranium minerals were discovered on the East Slope No. 2 prospect by John Henry of Marysvale and Don MacIntosh of Junction, Utah, in July 1950. The deposit is $3 \frac{3}{4}$ miles north-northwest of Marysvale in sec. 6, T. 27 S. , R. 3 W., Salt Lake meridian, Piute County, Utah, about 1 mile west of Bullion Monarch mine (fig. 1). It may be reached over approximately 6 miles of good graded road from Marysvale. The deposit is one of the few outside the central producing area (fig. 1) where autunite, metatorbernite, and 


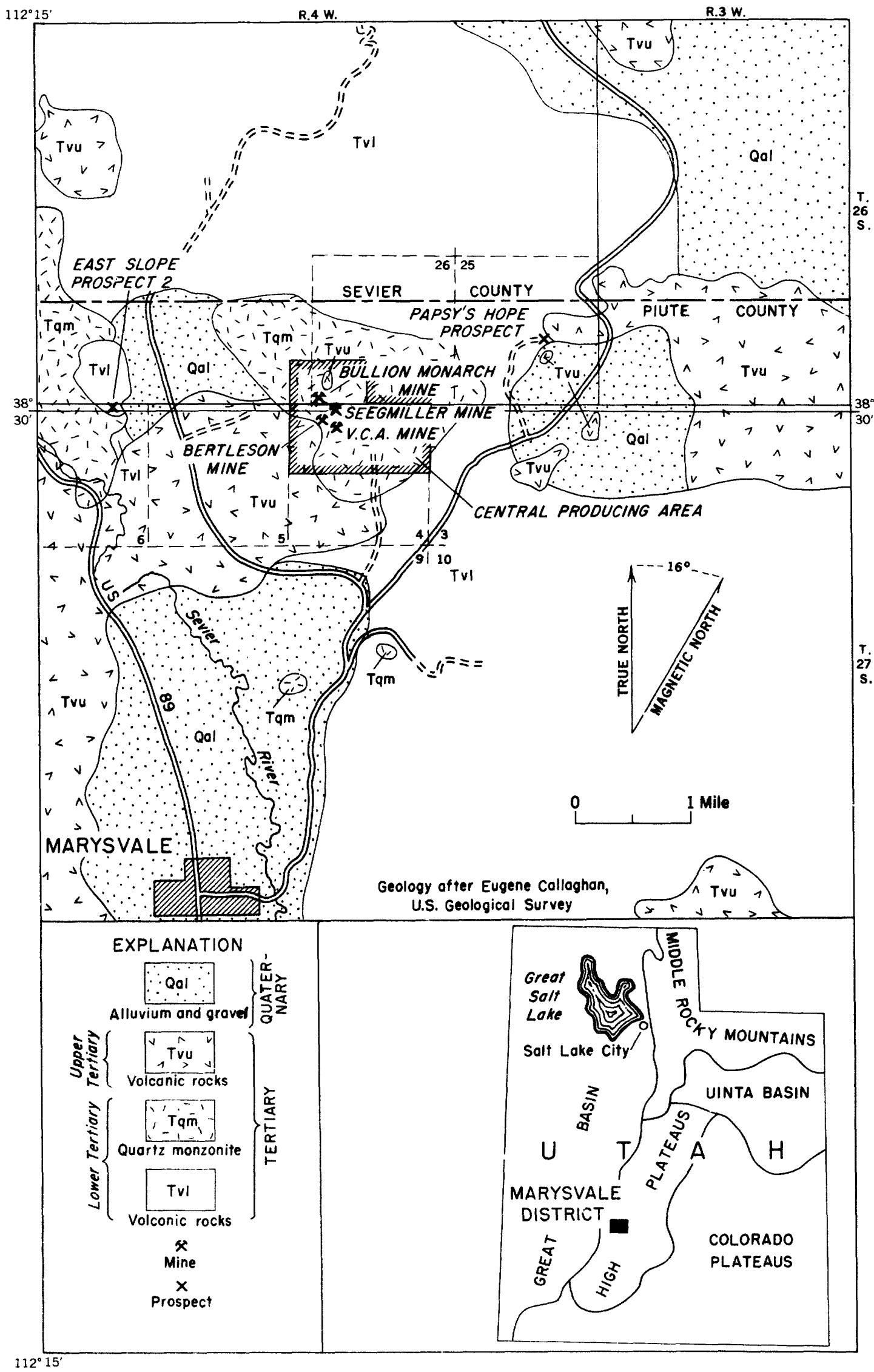

Figu: e 1. -Inde and geologic maps of the Marysvale district, Utah, showing the location of the East Slope No. 2 prospect. 
uranophane(?) have been found. It is developed by two shallow trenches and by two bulldozer cuts, one-the lower cut-at the time of mapping, was covered by the dump of the upper. Similar zones of altered and uraniferous rock were seen by the writer in the lower cut.

Since the preparation of this report the property has been leased to the Magnolia Lead Company of Salt Lake City. This company has sold one truck load of ore from the property to the Marysvale purchasing depot, and has driven a 50-foot adit under the deposit.

The East Slope No. 2 prospect was mapped as part of the U. S. Geological Survey's program for the evaluation of the uranium resources of the Marysvale region (Wyant, 1950) on behalf of the Division of Raw Materials of the U. S. Atomic Energy Commission. The general geology of the surrounding area has been mapped by Callaghan (1939). A plane-table map of the mine workings (pl. 1) and a detailed sketch section of the exposed workings (fig. 2) were made during four days in August.

Acknowledgment is made of the assistance of Mr. John Henry and Mr. Don MacIntosh in showing the writer their property. Mr. F. L. Klinger and Mrs. D. G. Wyant assisted in the geologic mapping. T. S. Lovering of the Geological Survey spent about half a day at the prospect and assisted greatly in identifying the types of alteration and comparing them with similar altered rocks in the Eureka district. Eugene Callaghan, also of the Geological Survey, visited the property with the writer and discussed the identification of the various rock types in relation to alunitic and other types of alteration in the Marysvale region.

\section{ROCK UNITS}

The volcanic rocks of the Marysvale district have been divided into an earlier Tertiary group and a later Tertiary group by Callaghan (1939,p. 438). His earlier Tertiary group consists of the Bullion Canyon volcanics: tuff and related volcanic rocks that have been intruded by quartz monzonite; his later Tertiary group consists of the Mount Belknap rhyolite and related extrusives. The two groups are separated by an unconformity and the exact ages of the rocks are unknown.

The Bullion Canyon volcanics and the related rocks in the area mapped have been converted to hornfels. Elsewhere in the Marysvale district they are latite, tuff, flows, and agglomerates.

The hornfels is predominately a dark-gray to green rock composed of white feldspar prophyroblasts in an aphanitic matrix. Subordinately, the hornfels is granular and gradational with the porphyroblastic variety. The granular hornfels is composed largely of fledspars, chlorite, and mica, with minor quartz and magnetite. Epidote was observed in this roek at a few places. The granular hornfels is charaeteristically gray to red, and weathers brown.

The Mount Belknap rhyolite is in faulf contact with hornfels at the southeast edge of the area mapped. It is a red facies of the formation and consists of tuffaceous and platy red rhyolite.

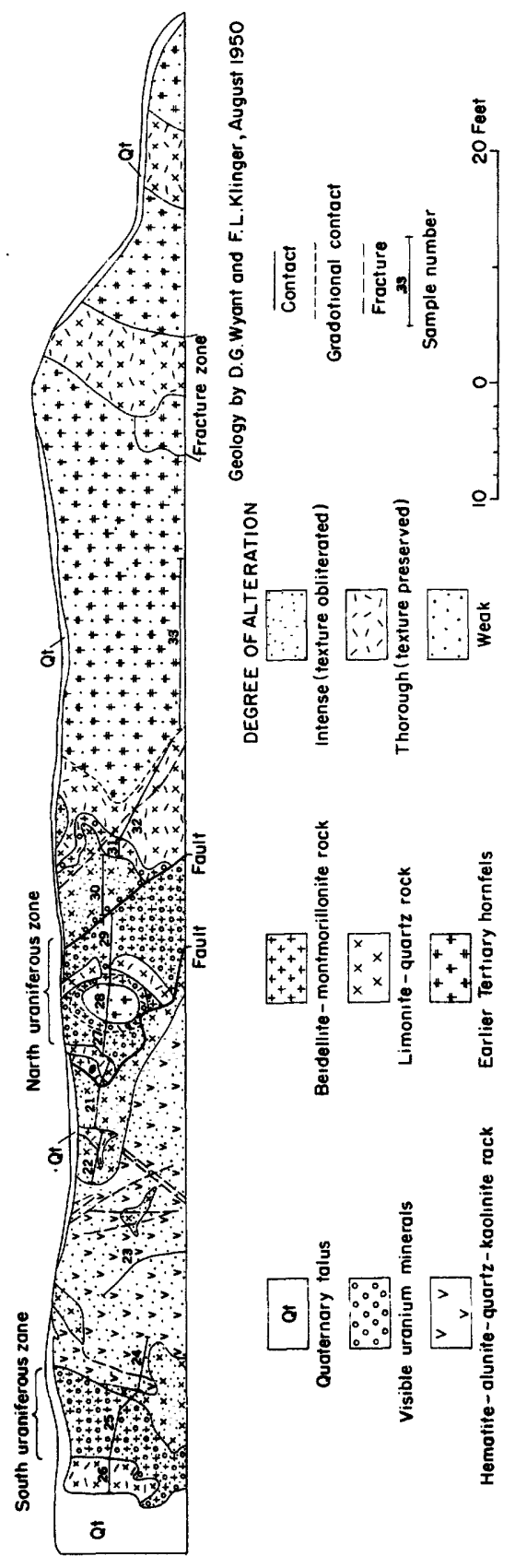

Figure 2,-Sketch section along west face of the upper cut, East Slope No. 2 uranium prospect, Piute County, Utah.

The quartz monzonite is a coarse-grained equigranular rock composed of plagioclase feldspar, orthoclase feldspar, and chlorite, and minor quartz and magnetite. Near the marrins of the quartz monzonite, migmatitic zones have been formed by partial assimilation of hornfels.

The three major types of bedrock in the area surrounding the East Slope No. 2 prospect are quartz monzonite, hornfels, and red (Mount Belknap) rhyolite. Their relationships are illustrated in figure 2. At the deposit, hornfels has been altered to hematite-alunitequartz-kaolinite and uraniferous beidellite-montmorillonite rocks. Nearby, the hornfels has been altered to a silicified hematite-alunite rock. These rocks are overlain by Pleistocene or Recent talus and alluvium. 
The East Slope No. 2 prospect is in hornfels near the eastern margin of a stock of quartz monzonite. This quartz monzonite stock is entirely separate from a similar stock that contains the larger uranium mines of the district (fig. 1). Hornfels, formed by the contact metamorphism of the Bullion Canyon volcanics, borders the quartz monzonite. Mount Belknap rhyolite, talus, and alluvium bound the older Tertiary rocks to the south, and are the surface rocks in the area between the East Slope No. 2 prospect and the quartz monzonite stock to the east that contains the principal uranium mines of the Marysvale district.

\section{STRUCTURE}

A fault of considerable, but unknown, displacement separates the Mount Belknap rhyolite southeast of the East Slope No. 2 prospect from the Bullion Canyon volcanics, the quartz monzonite, and the hornfels. Other faults within this older group of rocks strike west and dip from $54^{\circ}$ to $61^{\circ}$ south. They are of small displacement, erratic in trend, and formed either during or after the hydrothermal alteration of the rocks. Older faults, if present, may have been obscured by the hydrothermal alteration.

The rocks are moderately fractured; fractures of dominantly north-northwest strike form a conjugate set with fractures of dominantly east strike. The dip of the fractures is variable, but generally is steep.

The original structure of the hornfels is not readily discernible because planar structures other than fractures are generally lacking. The platy Mount Belknap rhyolite is essentially horizontal or dips gently eastward.

\section{URANIUM DEPOSITS}

\section{Character}

Tabular yellow-green uranium minerals, probably autunite, metatorbornite, schroeckingerite, and uranophane(?) are sparsely disseminated in two distinct zones: the north and the south uraniferous zones. The host rock in these uraniferous zones is white, buff, to srange argillized hornfels in which all or nearly all of the original textural features have been obliterated. The uraniferous zones have an east-west trend and dip from near vertical to $54^{\circ} \mathrm{S}$. The north zone is 3 to 10 feet thick and has been mapped a horizontal distance of 110 feet and a vertical distance of 70 feet. The south zone is 2 to 5 feet thick, at least 60 feet long, and has been traced intermittently for a vertical distance of 40 feet. Reddish float and altered hornfels suggest that both zones may extend over a vertical range of more than 100 feet.

The two zones are incompletely exposed as tabular bodies, but geologic relationships indicate that they may be connected and form a shell-like body around a central alunitic core (see pl. 1 and fig. 2). This central core consists of brick-red through purple to white, hematite-alunite-quartz-kaolinite rock in which none of the original textural features of the hornfels can be recognized. The relationship of these zones of alteration to the uranium minerals is illustrated in figure 2.
The uranium minerals form conspicuous, euhedral crystals, as much as a quarter of an inch across, at the margins of the uraniferous zones; here they coat fracture and joint surfaces in the weakly altered dense hornfels. This type of occurrence is analogous to the well-developed, coarsely crystalline uranium minerals that coat the fine-grained dense aplite or "granite" exposed in the Bullion Monarch open cut. In both places the well-crystallized uranium minerals do not necessarily occur in the highest grade ore. The higher grade ore, as in the Bullion Monarch open cut, consists, generally, of very fine grains of uranium minerals in a white to orange-buff clay gangue. By analogy with the operating mines of the central producing area, pitchblende may be expected to underly the secondary uranium minerals.

The highest grade material in the north uraniferous zone is in intensely argillized rock. One sample from this zone contained 0.043 percent equivalent uranium, ${ }^{1}$ and 0.047 percent uranium. The highest grade material in the south uraniferous zone also is in intensely argillized rock; one sample contained 0.032 percent equivalent uranium and 0.034 percent uranium.

\section{Alteration}

Callaghan (oral communication) has distinguished two main types of hydrothermal alteration in the Marysvale region: 1 , the pyritic type (pyrite, iron oxides, clay, alunite, and quartz), and 2 , the basemetal-gold type (quartz, carbonate minerals, pyrite, and fluorite). Subdivisions of these two types can be made according to the proportions of the various constituents. All types of alteration recognized at the East Slope No. 2 prospect are subdivisions of the pyritic type.

Three sub-types of pyritic type alteration that are based on mineral composition (determined partly by their color) were recognized at the prospect and are shown on fig. 3: 1, hematite-alunite-quartzkaolinite rock; 2 , beidellite-montmorillonite rock; and 3 , limonite-quartz rock. The alteration varies in intensity and the mineralogic types overlap.

The beidellite-montmorillonite rock was recognized in the field by the use of benzedine, a reagent that gives a distinctive color to the beidellitemontmorillonite group of clay minerals-blue when wet, yellow when dry (T. S. Lovering, oral communication). The benzedine reaction is a useful field test, but exact mineral identification requires more precise methods. The hematite-alunite-quartzkaolinite rock is faintly banded in places; white kaolinitic and alunitic rock forms poorly defined bands in the red or purple, more hematitic rock. The limonitequartz rock is orange to buff and contains varying amounts of fine-grained quartz and limonite stains and spots in a clay matrix. The arrangement of these

\footnotetext{
${ }^{1}$ Equivalent uranium is a measure of the total amount of radioactivity emitted by the sample, and is expressed as if all the radioactivity were due solely to uranium in equilibrium with the products in its disintegration series. The radioactivity of all radioactive substances, such as thorium, potassium $\left(\mathrm{K}^{40}\right)$, or uranium, would therefore be included as the percent equivalent uranium, if they were present. The equivalent uranium content of these samples was determined by Geiger-Mueller counters in the laboratory.
} 
three types o: alteration products is concentric, the hematite-quartz-alunite-kaolinite rock forms the core, the beidellite-montmorillonite rock forms the inner shell, and the limonite-quartz rock forms the outer shell.

The preliminary results of X-ray studies of specimens from the deposit are not conclusive (Theodore Botinelly, oral communication), but appear to indicate th: $t$ all three types of altered rock contain alunite, and that feldspar occurs with the beidell temontmorill. ite rock. Spectrographic analyses made by C. L. Waring of the Trace Elements laboratory, U. S. Geological Survey, are given in table 1. Of particular inlerest is the barium and vanadium content0.1 to 1.0 percent-in all samples, the increase in magnesium content from the core outward toward less altered rock, and the low content of iron in the beidellite-montmorillonite rock. These analyses, as well as those in table 2, indicate that the uranium content can be closely correlated with the beidellitemontmorillonite type of alteration which, in general, is outside the more intensely alunitized rock.

\section{Sampling}

Thirteen chip samples were taken in the upper bulidozer cut. They were cut at approximately right angles to the structure and represent each type of altered rock across the entire mineralized body. Another sample, DW-10-34, of white clay containing uranophane(?) was taken from the short trench above the upper bulldozer cut. The analyses of these samples are shown in table 2 (see also fig. 2). Of particular interest is the localization of the highest grade uranium in the beidellite-montmorillonite rock.

\section{OUTLOOK AND GUIDES TO PROSPECTING}

The eastern and western limits of the two uraniferous zones on the East Slope No. 2 prospect have not been determined. Trenches to bedrock along the 6670,6660 , and 6560 contours (pl. 1), across the areas covered with talus, might be expected to extend the known limits of these uraniferous zones, as well as to indicate where to do additional trenching. Because

Table 1.-Spectrographic analyses of samples from alteration zones, East Slope No. 2 uranium prospect, Plute County, Utah

$$
\begin{aligned}
& \text { Rock type } \\
& \begin{array}{llllll}
1.0 & \text { to } 10.0 & 0.1 & \text { t.c } 1 & 0 & 0.01 \text { to } 0.1
\end{array} \\
& \text { (percent) (percent) }
\end{aligned}
$$

Hematite-alunite-quartzl - Si, Al kaolinite rock.

Beldelite-montmorillonite Si, Al rock.

Iimonite-quartz rock-.-.-. S1, Al

$$
\begin{aligned}
& \mathrm{Fe} \\
& \mathrm{T1}, \mathrm{Ba}, \mathrm{Cr}, \mathrm{I} \mathrm{Sr}, \mathrm{Mg}, \mathrm{Ca}, \mathbb{P} \mathrm{Cu}, \mathrm{Y}, \mathrm{N} 1 \text {. } \\
& \mathrm{Pb}, \mathrm{Na}, \mathrm{Mn} \text {, } \\
& \mathrm{Zr} \text {. } \\
& \mathrm{K}, \mathrm{Na} \\
& \mathrm{Fe}, \mathrm{K}, \mathrm{Mg}
\end{aligned}
$$

Table 2.-Analyses of samples, East Slope No. 2 uranium prospect, Plute County, Utah

[Type of altered rock: A, hematite-alunite-quartz-loolinice rock; B, beidellite-Montmorillonite tock; C, limonite-quartz rock]

Locality
and
sample
no.
$\begin{gathered}\text { DW }-10-21 \\ -22 \\ -23 \\ -24 \\ -25 \\ -26 \\ -27 \\ -28 \\ -29 \\ -30 \\ -31 \\ -32 \\ -33 \\ -34\end{gathered}$

Description

(feet)

no.

5.5

\begin{tabular}{|c|c|c|}
\hline $\begin{array}{c}\text { Equivalent } \\
\text { uranium } \\
\text { (percent) }\end{array}$ & $\begin{array}{l}\text { Uranium } \\
\text { (percent) }\end{array}$ & $\begin{array}{l}\text { Type } \\
\text { of } \\
\text { altered } \\
\text { rocks }\end{array}$ \\
\hline $\begin{array}{r}0.016 \\
.009\end{array}$ & $\begin{array}{r}0.018 \\
.007\end{array}$ & $\begin{array}{l}\mathrm{C}, \mathrm{B} \\
\mathrm{C}, \mathrm{B}\end{array}$ \\
\hline $\begin{array}{l}.002 \\
.007 \\
.032\end{array}$ & $\begin{array}{l}.002 \\
.006 \\
.034\end{array}$ & $\begin{array}{l}\mathrm{A} \\
\mathrm{A} \\
\mathrm{B}, \mathrm{C}\end{array}$ \\
\hline $\begin{array}{l}.018 \\
.009 \\
.014\end{array}$ & $\begin{array}{l}.018 \\
.011 \\
.020\end{array}$ & $\begin{array}{l}\mathrm{C} \\
\mathrm{B}\end{array}$ \\
\hline .043 & .047 & $B, C$ \\
\hline $\begin{array}{l}.017 \\
.032 \\
.006 \\
.004 \\
.021\end{array}$ & $\begin{array}{l}.021 \\
.040 \\
.004 \\
.002 \\
.005\end{array}$ & $\begin{array}{l}\mathrm{C} \\
\mathrm{B} \\
\mathrm{C}\end{array}$ \\
\hline
\end{tabular}

Orange-red altered rock-

5.1 Pink altered rock, south of Sample no. DW-10-21.

8.6 Hematite-alunite-quartz-kaolinite rock------

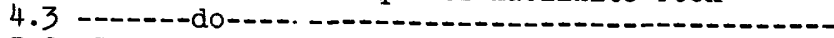

5.2 South raniferous zone, orange to buff clay; some quartz.

3.8 Orange to brown clay, south of ne. DW-10-25--

2.6 White -o orange clay, north of no. DW-10-21--

2.2 Gray spotted hornfels, north of no. DW 10-27.

4.5 North uraniferous zone, white clay with uranium minerals.

4.7 Orange, altered hornfels; sparse torbernite--

c.0 Mauve potted hornfels; visible torbernite---

11.5 Brown to gray spotted hornfels......

10.0 Silver to gray spotted hornfels...............

3.6

White clay with yellow stains from trench west if (above) upper cut. 
of the irregular distribution of uranium minerals in secondary deposits these trenches might be expected to uncover rock of appreciably different uranium content.

In other parts of the Marysvale district, pitchblende, which may constitute higher grade ore, underlies secondary uranium minerals; therefore, exploration by drilling or drifting at levels 100 to 200 or more feet below the present exposures offers the possibility of finding better-grade ore. The absence of information about the vertical extension of the known deposits at this prospect, however, makes such exploration economically hazardous.

The occurrence of secondary uranium minerals with beidellite-montmorillonite rock in zones peripheral to hematite-alunite-quartz-kaolinite rock suggests that prospecting of this general type of altered rock in the surrounding area might be fruitful. The beidellite-montmorillonite rock weathers readily and therefore forms inconspicuous outcrops. The use of the benzedine test should aid in the field identification of this rock.

\section{ITTERATURE CITED}

Callaghan, Eugene, 1939, Volcanic sequence in the Marysvale Region in southwest-central Utah:

Am. Geophys. Union Trans., part 3, p. 438-452.

\section{UNPUBLISHED REPORTS}

Callaghan, Eugene, Unpublished maps of the Marysvale, Sevier, Monroe, Delano Peak, and Beaver quadrangles, Utah.

Wyant, D. G. , Stugard, F., Jr., and Kaiser, E. P., 1950, Uranium resources in the Marysvale region, Utah, An Interim Report: U. S. Geol. Survey, Trace Elements Memorandum Rept. 169. 


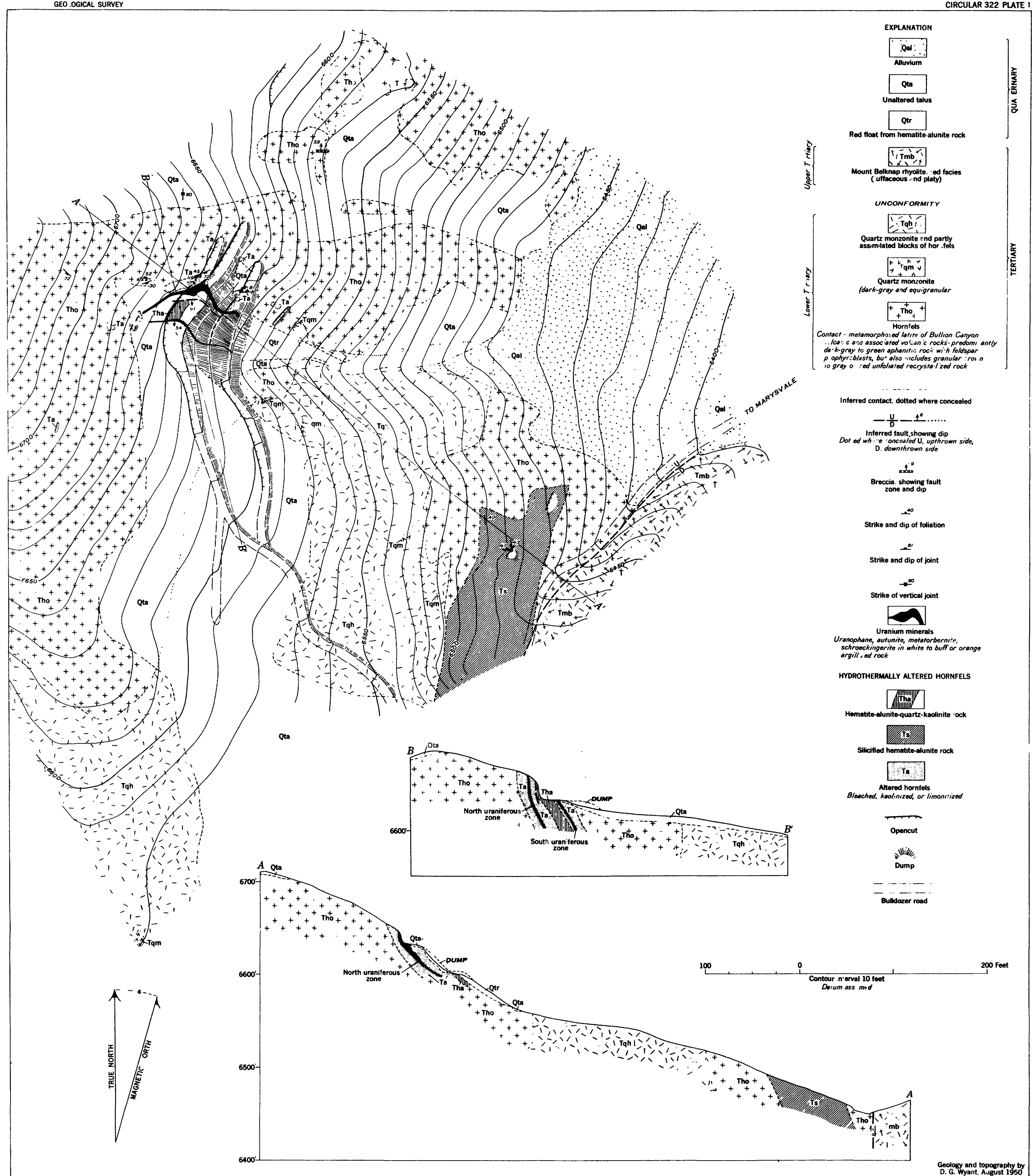

